\title{
Europeanization and the Rule of Law: Towards a Pathological Turn
}

\author{
Martin Mendelski \\ Max Planck Institute for the Study of Societies, Cologne, Germany \\ Alexandru Ioan Cuza University, Iasi, Romania \\ mendelski@mpifg.de
}

\begin{abstract}
Recent scholarship has exposed the "EU's pathological power", which has undermined the creation of the rule of law in South Eastern Europe (SEE) and beyond. This paper discusses the "pathological turn" in Europeanization studies by identifying and providing evidence for several "pathologies of Europeanization", i.e. legal and political deficiencies related to rule of law reform, such as legal instability, lack of generality and enforcement, and increased politicization. These pathologies result, among others, from a deficient approach of the EU to rule of law promotion and assessment. In particular, the author highlights three main fundamental problems of Europeanization in the area of the rule of law: 1) valuing quantity over quality; 2) partisan empowerment of domestic change agents; and 3) biased assessment of the rule of law. These problematic issues are further clarified on selected country examples of reform failure from SEE and the 2012 "rule of law crisis" in Romania. It is argued that given the EU's inability to objectively assess and effectively promote the rule of law, the Eu should either abstain from evaluating rule of law or radically revise its approach and methodology, for instance by following the policy advice provided in this paper.
\end{abstract}

\section{Keywords}

rule of law - European Union - pathologies of Europeanization - constitutional crisis - South Eastern Europe - Western Balkans - Romania - Moldova

\section{Article by an MPIfG researcher}

Martin Mendelski: Europeanization and the Rule of Law: Towards a Pathological Turn. In: Southeastern Europe 40(3), 346-384 


\section{Introduction}

How does the European Union (EU) affect the development of the rule of law in accession and membership countries? This fundamental question has been debated by political scientists and legal scholars in a controversial way. The first generation of Europeanization scholars argued that the EU's impact is mainly positive, i.e. that the EU has democratization and transformative power (Ekiert et al. 2007; Vachudova 2005; Grabbe 2006). The second generation of scholars, on the other hand, maintained that there are limits to the Eu's transformative power due to unfavorable domestic conditions (e.g. Magen and Morlino 2009; Dallara 2014). Now, a third generation of scholars has revealed several "pathologies of Europeanization" (Börzel and Pamuk 2012; Mendelski 2014) and the "EU's pathological power" (Mendelski 2015). This more critical strand of literature has argued that the EU undermines the rule of law (Pech 2015; Slapin 2015; Mendelski 2015), democracy (Börzel 2015) and good governance (Börzel and Pamuk 2012; Mungiu-Pippidi 2014), for instance by applying deficient and inconsistent methods to promote rule of law and democracy (see Schimmelfennig 2012; Börzel 2016; Börzel and van Hüllen 2014).

It seems that by drawing attention to negative and pathological effects of $\mathrm{EU}$ conditionality, the Europeanization literature has become more pessimistic, or better said, more realistic about the EU's ability to promote democracy and the rule of law in accession countries from South Eastern Europe (SEE) and the European Neighborhood (see Schimmelfennig 2012). This recent sobering evaluation of the EU's soft power and effectiveness of conditionality reflects the empirical deterioration of the rule of law and democratic quality in the region, as well as a "pathological turn" in Europeanization studies, which is the central focus of this article.

The notion "pathologies of Europeanization" was first mentioned in an article written by Tanja Börzel and Yasemin Pamuk. These authors exposed the "dark side of Europeanization" and argued that

Europeanisation can have unintended and negative effects on the domestic structures of states. EU policies and institutions not only empower liberal reform coalitions, to the extent that they exist in the first place, but can also bolster the power of incumbent authoritarian and corrupt elites...

BÖRZEL AND PAMUK 2012: 81

The empowering of illiberal and reformist elites thus occurs as a consequence of the instrumentalization of anti-corruption reforms. 
Similarly, Jonathan Slapin has claimed that the Eu may undermine the rule of law in emerging democracies by creating incentives for rule evasion and disrespect. He argued that "[i]nternational pressure may create perverse incentives for governments to draft laws that both they and their citizens have no intention of obeying" (Slapin 2015: 628). He explained this perverse pathological effect by the fact that in some countries the laws that have been transplanted and imposed by the EU (e.g. acquis communautaire) have little demand, legitimacy and support from citizens, law-makers and law enforcers, and that this lack of demand and understanding may reduce the respect for the rule of law (Slapin 2012).

In previous research, I have empirically analyzed the EU's impact on the rule of law in post-communist countries from CEE (Mendelski 2013, 2014, $2015,2016)$. My work shows that EU-driven rule of law reforms often result in a considerable increase of judicial capacity and substantive legality (i.e. the approximation to Western standards), but they have a negatively reinforcing (i.e. a pathological) impact on judicial impartiality and formal legality - the "inner morality of law" (Fuller 1969) - for instance by producing "legal pathologies", that is, more unstable, incoherent and less enforced laws. In my latest article published in Southeastern Europe (Mendelski 2015) I coined the notion of the "EU's pathological power" and argued:

EU-driven rule of law reforms are not transformative and even have pathological power, that is, a negatively reinforcing effect. Thus, rather than strengthening the rule of law, the $\mathrm{EU}$ and domestic reformers (change agents) contribute paradoxically to its overall weakening. The EU's pathological power, though, is an indirect effect, as its outcome depends on a country's domestic conditions, and in particular on the already existing level of its rule of law and the way in which reforms are conducted.

MENDELSKI 2015: 319

In my PhD dissertation (Mendelski 2014), I provided a more differentiated argument on the EU's effectiveness in rule of law promotion. I have argued that the degree of legal pathologies depends on a country's social order. I discovered that countries with an already weak rule of law (e.g. Romania and Moldova) suffer more from the pathological impact of EU conditionality than countries with a strong rule of law (e.g. Poland and Estonia). The reason why the EU has less pathological power in consolidated countries with a strong rule of law is that reformers (and the EU) are more effectively constrained by reform-resisting and independent horizontal accountability institutions 
(e.g. Constitutional Courts, Ombudsmen, judicial councils) and are therefore less able to abuse and instrumentalize the law, the newly created judicial structures and the rule of law reform. This contrasts with the unchecked reformers in SEE and the Commonwealth of Independent States (CIS), which are able to capture and politicize newly created judicial and anti-corruption structures during the reform process. In short, reforms can both consolidate and undermine the rule of law. What makes the difference is the quality of the reform process, which in turn depends on the underlying political, legal and socio-economic conditions in the country in which domestic actors (reformers) are embedded.

This paper aims to elaborate on the notion of pathologies of Europeanization in the area of the rule of law, and by so doing contributes to the "pathological turn" in Europeanization studies. I argue that the European integration process may undermine the "inner morality" of law (i.e. the stability, generality and enforcement characteristics of law) and increase politicization and instrumentalization of newly created or newly empowered judicial structures. The reason for this pathological effect is related to three fundamental problems of Europeanization: 1) valuing quantity over quality; 2) partisan empowerment of domestic "change agents"; and 3) biased assessments of the rule of law. The implication of the pathological turn in Europeanization research is clear. EUdriven judicial, anti-corruption and legal reforms can negatively affect the rule of law, especially when the partisan and inconsistent application of EU conditionality enables reformers to misuse the rule of law (and reforms) as a political weapon (Maravall 2003) against critical members from the judiciary or the opposition. Thus, more reform may not necessarily result in more progress, and may instead lead to a deterioration of the rule of law.

The article is structured as follows. Section 2 identifies and conceptualizes pathologies of Europeanization in the area of the rule of law, while Section 3 provides empirical evidence for legal pathologies in SEE by resorting to several objective and subjective indicators. Section 4 then explains how the EU has reinforced reform pathologies and "rule of law crises" through the application of a flawed approach to rule of law promotion and assessment, as reflected in the three fundamental problems of Europeanization. The conclusion argues that the EU is not well suited to promote, protect and assess the rule of law.

1 Change agents are domestic, reformist "norm entrepreneurs" who have been typically socialized and trained in "epistemic communities" (Haas 1992). They promote legal, judicial and anti-corruption reforms in order to adapt to European/Western liberal standards (the rule of law, liberal democracy and constitutionalism, human rights, etc.). 
It proposes concrete policy recommendations on how to improve this inherent deficiency.

\section{Conceptual Framework: Pathologies of Europeanization}

\subsection{The Rule of Law: a Multi-Dimensional Concept}

I conceive the rule of law as a multi-dimensional concept of governance which can be distinguished into four interrelated dimensions: 1) formal legality; 2) substantive legality; 3) judicial capacity; and 4) judicial impartiality (see Mendelski 2015). While the first two dimensions refer to the quality of rules, the latter two dimensions assess the quality of the judicial system. Formal legality can be evaluated by the degree of legal stability, coherence, generality and enforcement (Fuller 1969: 46ff). Substantive legality is reflected in the presence of good laws that ensure certain principles (e.g. justice and equality before the law) and certain rights (civil, political, and socio-economic human rights) (Tamanaha 2004). Judicial capacity refers to the inputs, means, and resources required to establish a capable judicial system (e.g. quantity and quality of human, technical and financial resources). Judicial impartiality refers to the unbiased and impersonal enforcement of law by independent, accountable and impartial magistrates who are bound by law. Finally, all four dimensions of the rule of law are interdependent and influence each other. For instance, there is no rule of law without good laws, even if the judiciary might be capable and independent. And vice versa: despite the presence of good laws, there might be corrupt, biased and incapable judges who may not enforce these laws and thus weaken the rule of law. Let me now elaborate theoretically on the potential legal and reform pathologies which might occur during (EU-driven) reforms. These "pathologies of Europeanization" impact on the formal legality and judicial impartiality dimensions in a negative way.

\subsection{Reform Pathologies of Europeanization}

Judicial and legal reforms have been generally hailed as the panacea to establish the rule of law, both by practitioners, the EU and academic scholars. The experience of pre-accession countries shows, however, that reforms did not automatically lead to progress and have in many cases undermined the rule of law. Why is this the case? The answer to this question can be found in a deficient approach to reform, which reinforces legal pathologies that undermine the quality of the law and the quality of the judicial system. These reform pathologies of Europeanization can be conceptualized in the following way. 


\subsubsection{Legal Instability/Inflation}

First, (EU-driven) reforms can potentially undermine the stability of law. Reforms that are too speedy and ill prepared can produce detrimental effects on the quality of legislation. Reforms are based on the adoption of formal rules. Overzealous reforms can undermine formal legality by producing too many laws, becoming unstable as well as incoherent as a consequence of frequent amendments. The literature on EU accession has already noticed this detrimental effect of the EU on the inner quality of law, and has in particular criticized hasty rule adoption without democratic deliberation (see Sadurski 2004).

\subsubsection{Lack of Enforcement of Law}

Enforcement of law means that there must be "congruence between official action and declared rule" (Fuller 1969: 46ff), i.e. that laws are enforced and implemented. In other words, the discrepancy between the rules of the books and behavior in practice should be minimized. EU-driven reforms may result in a lack of enforcement and implementation, producing empty shells and non-compliance (Noutcheva 2009). This pathology is often attributed to domestic costs and to "veto players" 2 who block the implementation of new laws (Magen/Morlino 2009; Sedelmeier/Schimmelfennig 2005). The main question, then, is why international donors (including the $\mathrm{EU}$ ) insist on transplanting "their" "first-best" laws from a more advanced system, which however do not work sufficiently well under domestic conditions and even undermine the respect for law (Slapin 2012). This may be explained, for instance, by the EU's predominant focus on the external morality of law (e.g. adoption of universalistic human rights, best standards of good governance and Western standards).

\subsubsection{Lack of Generality of Law}

Generality of law means that "the law must act impersonally, that its rules must apply to general classes and must contain no proper names" (Fuller 1969: 47). In other words, there must be general rules (general principles of conduct) that do not refer to individual persons or to local, occasional or special interests. Otherwise, legislating would reflect a "series of sporadic and patternless exercises of power" (Fuller 1969: 110). Reforms may negatively affect the generality of laws, for instance through the instrumentalization of law as a political weapon (Maravall 2003) and "state capture" (Hellman et al. 2003), that is, "the efforts of firms to shape the laws, policies, and regulations of

2 Veto players are institutional or political domestic actors whose agreement is necessary to change the status quo. They are typically reform opponents who tend to oppose EU-induced judicial and anti-corruption reforms and the way in which these reforms are conducted. 
the state to their own advantage by providing illicit private gains to public officials". ${ }^{3}$ State capture has been attributed in the literature to captor firms associated with oligarchs, corrupt personalities and reform opponents - so not necessarily the ideal agents to conduct reforms. Unfortunately, the EU has in many cases empowered such questionable and powerful domestic "change agents", but also "veto players" (Börzel and Pamuk 2012; Mendelski 2015; Kubicek 2016). ${ }^{4}$

If we consider that both types of domestic actors are embedded in the same social order (of a weak rule of law based on closed access), we may wonder whether these actors really differ in their behavior towards the law. We may wonder whether these embedded reformers are really able to see the law as a general constraint, or whether they employ it rather in an ad hoc way as an instrument for advancing their own interests (or the interests of their sponsors/ networks) or to fight their political or economic competitors. Whatever the interests, motivations and intentions of reformers are, what may suffer during reforms is the inner morality of law (and in particular the aspect of generality). The main problematique is whether pro-Western domestic reformers should be empowered through sporadic amendments of the law (or even of the Constitution) when this kind of legal and personalized empowering may undermine the generality of rules.

\subsubsection{Politicization of judicial structures}

It is not only laws and reforms that can be instrumentalized. The same is also true for old and newly created judicial and prosecutorial structures (e.g. horizontal accountability institutions). The politicization and instrumentalization of newly established anti-corruption agencies and judicial councils, as well as new specialized courts and constitutional courts, has been noted in several case studies from SEE (Bozhilova 2007; Ivanova 2013; Capussela 2015; Beširević 2014; Kuzmova 2014; Mendelski 2015). The main risk for the rule of law here is that even reformers with "good intentions" may take control of these newly transplanted or empowered structures and utilize them in an arbitrary, nontransparent, non-democratic or non-accountable way, for instance to advance particularist or hegemonic political interests (Hirschl 2009). We may therefore speak of the pathology of "institutional capture" as the "de facto takeover of entire state and public institutions" to advance particularist interests, "typically

3 See https://www.imf.org/external/pubs/ft/fandd/2001/og/hellman.htm.

4 These EU-empowered "change agents" are, among others, questionable oligarchs (e.g. in Ukraine and Moldova), authoritarian leaders (e.g. Caucasus, Turkey), or politicians involved in corruption scandals (e.g. Croatia, Romania) and even criminal activities (e.g. Kosovo). For details see footnote 8 . 
by an elite cartel of political and business oligarchs" (Karklins 2005: 29). The captured state institutions include regulatory agencies, courts and federal state structures (Polischuk 2008), and judicial councils (Garoupa and Ginsburg 2009: 63), as well as oversight institutions, anti-corruption agencies, and prosecutorial, executive and legislative structures (Mendelski 2015). The main question is not only "who guards the guardians?" (Shapiro 1998), but equally, "who guards the reformers?" This question concerns the oversight of all potential reformers, consisting of transnational coalitions between external and domestic reformers, as well as empowered judicial structures (e.g. Constitutional Courts and anti-corruption agencies), which are blamed for representing hegemonic interests and undermining the common interest of the demos (Caplan 2005; Hayden 2005; Hirschl 2009).

\section{The Pathological Turn: Empirical Evidence for Pathologies of Europeanization}

\subsection{Legal instability}

The first reform pathology of Europeanization, which was reinforced during the pre-accession period of intensified reform in SEE, is reflected in the increased number of adopted legislation (see Figure 1). Legislative growth potentially produced legislative instability because new laws have been introduced through amendments of the legal framework. Between 2001 and 2015 the legislative output indicator, which reflects the number of adopted laws per year, increased for the Western Balkan countries by $98 \%$. In Romania and Bulgaria, where EU conditionality started already in 1995, the legislative output grew considerably, i.e. from 132 to 782 adopted laws per year in Romania between 1995 and 2001, and in Bulgaria from 121 to 210 adopted laws per year (between 1995 and 2006). Considerable increases in the number of adopted laws per year were also experienced by Serbia (from 47 to 265) and Croatia (from 182 to 308) between 2003 and 2009, as well as by Macedonia (from 149 to 606) between 2009 and 2015. A substantial part of this growth in legislative output and instability can be explained by the eu's external pressure and the domestic zeal for (politicized) reform. The coercive and mimetic isomorphism (see DiMaggio/Powell 1983) of Europeanization resulted in multiple legislative packages and accelerated measures of legislating that aimed to align domestic laws with the acquis communautaire and international liberal norms. Legislating was typically done by empowered reformist elites from the executive and undermined in many instances the stability of law as well as the democratic rule adoption process (see Sadurski 2004; Risteska 2013; Goetz and Zubek 2007; Mendelski 2015). 


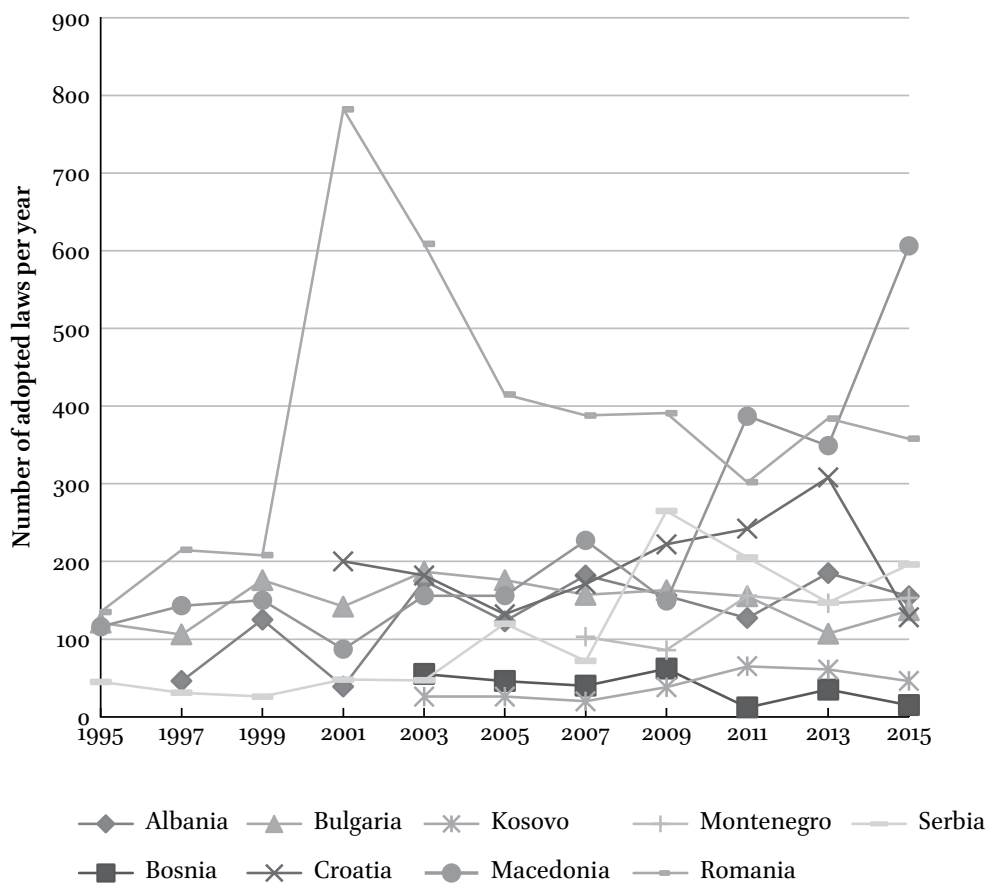

Source: National parliaments. Numbers compiled by the author.

FIGURE 1 Development of formal legality (legislative output) in SEE

\subsection{Lack of generality of law}

The second pathology that characterizes SEE is a lack of general laws. In other words, there is particularistic legislation due to state capture, which benefits certain groups or actors. To measure the generality of laws I use the proxy indicator on corruption in the parliament/legislature from Transparency International (Figure 2). This indicator measures the perception of legislative corruption and reflects state capture. The relatively low scores for countries from SEE indicate that the interests of powerful business companies play a strong role in influencing the legislative process as well as the enforcement of law in this region (see Hellman et al. 2003). This influence of vested interests is reflected in a lower quality of generality, because laws are amended in order to fulfill particular interests of influential captors. What about the trend? The TI indicator on legislative corruption indicates that there is a slightly declining trend in the perception of legislative corruption, which could be interpreted as a degeneration of the generality of legislation. The average indicator declines for this region by -0.2 between 2004 and 2013. It worsened considerably in Kosovo (-1.5) and Albania (-0.9) and improved in Macedonia (+0.7). In all other countries it stagnated at a similarly low level. The lack of general rules remains a considerable problem in the region. 


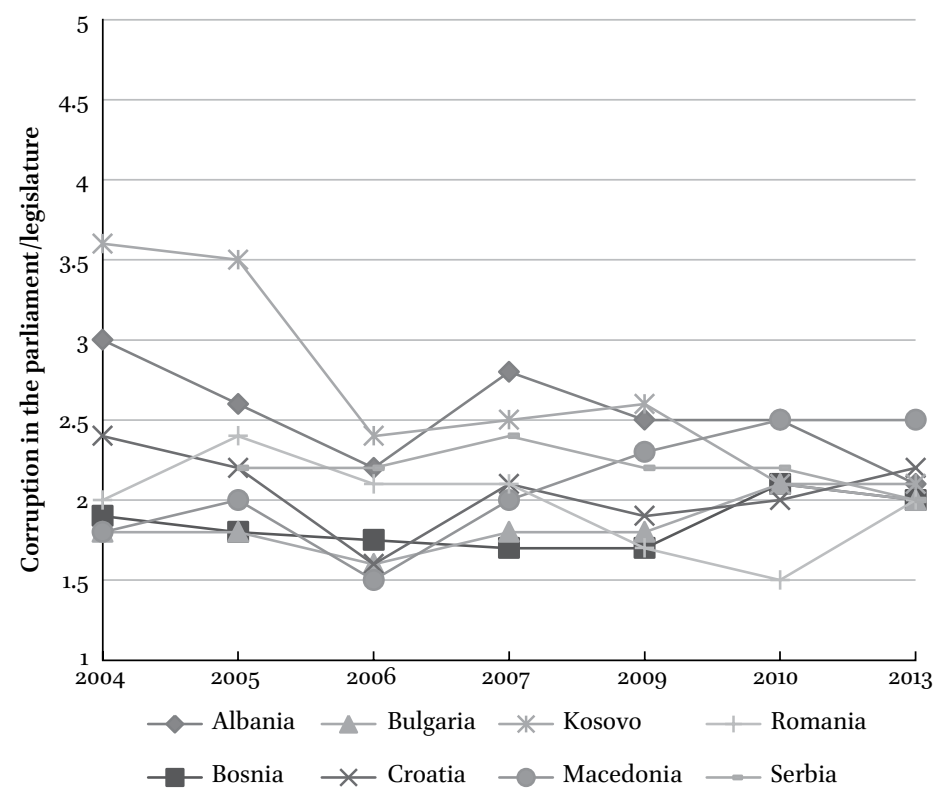

Source: Global corruption barometer, transparency international.

Note: Scale from 1 (worst performance) to 5 (best performance). The original scores were reversed, so that higher values indicate less corruption.

FIGURE 2 Legislative corruption in SEE

\subsection{Lack of enforcement}

The third pathology concerns lack of enforcement of law. The regulatory enforcement indicator provided by the World Justice Project (Figure 3) indicates that the enforcement of laws remains a continuous pathology in SEE. The general trend points to consolidation in the median range, suggesting that many transplanted and adopted laws are not enforced in practice. This sobering finding on the lack of implementation has been noted in the literature (Falkner et al. 2008; Elbasani 2013; Slapin 2015) and expressed in the author's interviews with judges and NGO representatives from the region.

\subsection{Politicization of judicial structures}

Politicization of newly created or established judicial structures is the fourth pathology that tends to occur during periods of reform. Is there any evidence for the politicization and capture of state institutions (including newly created judicial and anti-corruption structures)? Figure 4 shows the development of a judicial independence indicator for SEE for the period between 2002 and 2012. Two important observations can be made. First, on average, judicial independence increased slightly from 2.8 to 3.1 points between 2001 and 2014 . This increase probably reflects the empowerment of the judiciary through 


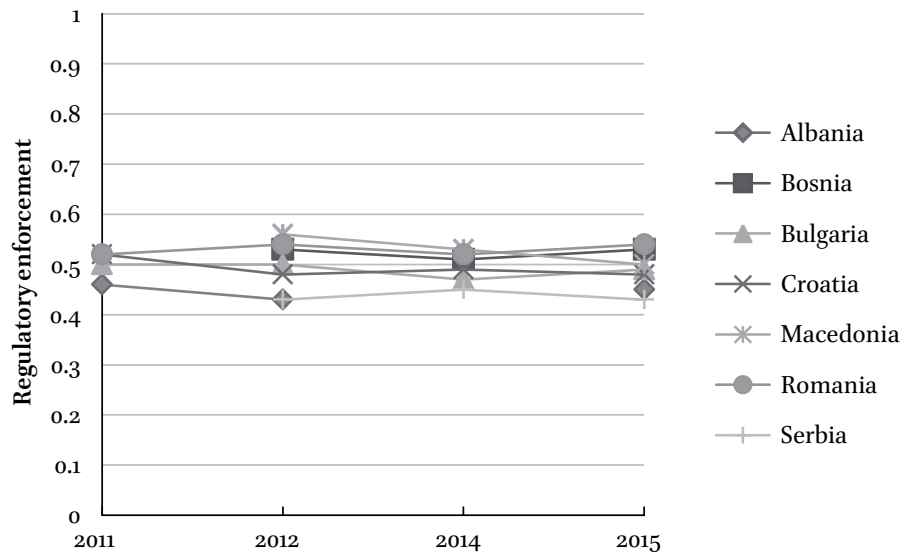

Source: World justice project.

Note: The regulatory enforcement indicator measures the extent to which regulations are fairly and effectively implemented and enforced. Strong rule of law adherence requires that: 1) these regulations and administrative provisions are enforced effectively; 2) government regulations are applied and enforced without improper influence; 3 ) administrative proceedings are conducted timely, without unreasonable delays; 4) due process is respected in administrative proceedings; and 5) there is no expropriation of private property without adequate compensation.

FIGURE 3 Regulatory enforcement in SEE

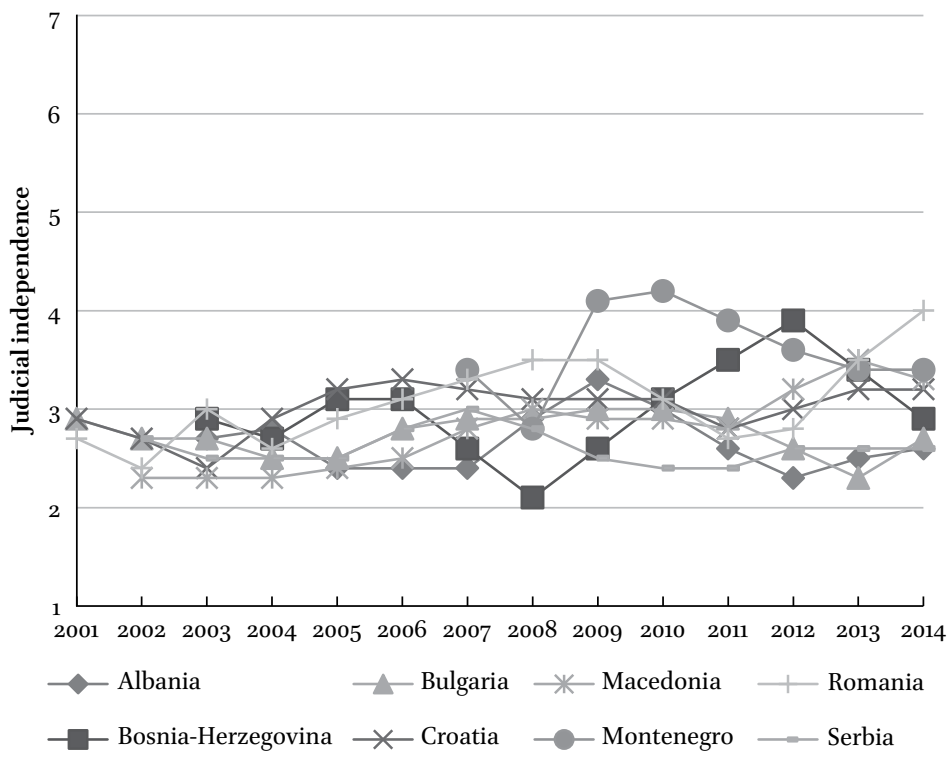

Source: World economic forum's executive opinion survey (wefeos).

FIGURE 4 Development of judicial independence in SEE 
de jure measures, the establishment of judicial councils and capacity building. On a negative note, while judiciaries and judicial councils became more independent, they also became less transparent and less accountable during this period (Bobek/Kosar 2014). Second, when looking at the country-level data, we can observe that judicial independence experienced considerable fluctuation, with increasing and declining trends. It is most reasonable to interpret these fluctuations as periods of empowerment and disempowerment of the judiciary (e.g. through the Judicial Council). In other words, these ups and downs correlate with changes in government and reflect reshuffling of (high-level) judges and prosecutors in key positions, which occurred during court restructuring and politicized judicial reforms in several countries from the region.

Overall, the empirical evidence points to the presence of several pathologies affecting the inner quality of legislation (stability, coherence, generality, enforcement) and the quality of judicial structures (politicization, lack of accountability). When analyzing the trends we can perceive stagnant and declining developments of the selected indicators (except for judicial independence, which improved slightly although with considerable fluctuation). These sobering results suggest a negatively reinforcing (i.e. pathological) impact of EU conditionality and rule of law reform. In the next section, I will explain the reinforcement of these pathologies through three fundamental problems of Europeanization. ${ }^{5}$

\section{4}

\section{Explaining Pathologies of Europeanization}

What accounts for pathologies of Europeanization? Why is the EU not able to improve the rule of law in already weak rule of law countries? The answer to this question is complex and relates to internal and external factors. This section focuses at the central external reason for reform failure: a deficient EU conditionality. In particular, I identify three fundamental problems of Europeanization in the area of the rule of law that undermine the establishment of the rule of law in SEE and beyond.

5 However, it should be noted that legal pathologies can also be explained through domestic explanations (inherited structural factors, informal institutions, etc.), which I cannot elaborate upon in full here due to space constraints. At the end, only detailed case studies based on process-tracing and qualitative evidence are able to reveal the complex causalities (between structure, agency and the reform process) underlying the pathologies of Europeanization in each country. 


\subsection{The Problem of Valuing Quantity over Quality}

The first fundamental problem of Europeanization is reflected in the Eu's quantitative approach to rule of law promotion, which follows essentially a "the more the better" mindset in the assessment of the rule of law (i.e. more transplanted laws are better than few laws, more judicial independence is better than less independence, etc.) (see Mendelski 2016). The EU's approach to rule of law promotion and assessment thus emphasizes reforms that stress quantitative outcomes (more laws, more resources, more convictions, more arrests, etc.) over the qualitative reform processes and procedures (i.e. how laws, arrests or convictions are made). An illustrative example from the Western Balkans might suffice here to elucidate the Eu's quantitative approach. A typical Twinning Project evaluation fiche on organised crime and corruption in this region mentions the following quantitative indicators to measure progress: number of serious crime cases dealt with, number of witnesses coming forward, number of meetings, exchange programmes and participants, number of documents produced, number of technical arrangements, number of legislative standards, number of rules of procedure and guidelines drafted and adopted, number of judges and prosecutors trained, number of national key and secondary legislation drafted and adopted, number of legislation and cooperation agreements in place, ratio of information on best practice successfully exchanged and applied, number of training courses provided, and number of working groups established. ${ }^{6}$

However, by relying on this kind of "more is better" mindset, the EU (together with other international donors) has produced and reinforced legal pathologies that have undermined the rule of law in many CEE countries. The demand for more transplanted laws and adaptation to international standards has improved the external legality of law but at the same time has fostered legal inflation and instability (Mendelski 2015). The demand for more regulations, furthermore, has increased the discrepancy between formal rules and informal practice (Slapin 2012, 2015), and the call for more judicial independence has resulted in more independent but less accountable judicial councils (Bobek/Kosar 2014; Coman 2014). Similarly, the demand for a "solid track record" in fighting high-level corruption cases has increased the number of convictions, but has also lead to more instability of anti-corruption legislation and a misuse of newly established prosecutorial structures, including the violation of fundamental rights (Di Puppo 2010; Ivanova 2013; Capussela 2015). The demand for more judicial capacity, for its part, has created expensive information

6 http://ec.europa.eu/enlargement/pdf/financial_assistance/ipa/2012/multi-beneficiary/pf5_ ipa-2012_winpro-ii_final.pdf. 
and court administration systems (based on Western technology and software) that are hardly sustainable and remain dependent on continuous foreign assistance. ${ }^{7}$ Finally, more material resources (in the form of Eu funds) have resulted in more opportunities to engage in corruption and rent-seeking activities (Mungiu-Pippidi 2014).

Overall, the EU's quantitative approach, with its perverse incentives, has produced or reinforced several pathologies that have undermined crucial aspects of the rule of law. The EU and domestic reformers therefore face a "change vs. stability dilemma", which essentially refers to the opportunities for and challenges of improving the external morality of the law (substantive legality) whilst not undermining its inner morality (i.e. its stability, coherence and enforcement). This dilemma is especially pertinent (and unresolved) in weak rule of law countries from SEE and the former Soviet Union.

\subsection{The Problem of Partisan Empowerment of Change Agents}

The second fundamental problem concerns the EU's partisan empowerment and support of reformist domestic change agents, no matter how undemocratically they behave (see Mendelski 2015). EU conditionality is based on the socalled "differential empowerment" of domestic actors (Börzel and Risse 2003), which empowers few selected "liberal", reformist change agents to the detriment of so-called "illiberal" reform opponents (veto players) (see Magen/Morlino 2009). This partisan empowerment of change agents has been reflected, for instance, in the EU's support for reformist, pro-EU, but very controversial political change agents, ${ }^{8}$ as well as politically-selected, rule-of-law-abusing heads of newly introduced or strengthened judicial structures (e.g. judicial councils, specialized courts, Constitutional courts, and anti-corruption and integrity agencies). The key problems of empowerment are twofold.

First, such an agency and elite-oriented policy might be effective to achieve regime changes and electoral outcomes, but it is less suited to improve processes of governance (including the rule of law). This is related to the social embeddedness of reformist agency in a particularist structure of weak rule of law. In other words, reformist change agents are not able to escape their

7 Interview with course instructors in Moldova.

8 Filat and Plahotniuc (Moldova), Yatsenyuk, Poroshenko, Yushchenko and Timoshenko (Ukraine), Gruevski (Macedonia), Sanader (Croatia), Borisov (Bulgaria), Berisha (Albania), Basescu (Romania), Sakashvilli (Georgia) and Thaçi (Kosovo). Interestingly, most of these heads are members of European People's Party or closely linked to it. See http://european movement.eu/news/epp-leaders-meet-for-party-summit-ahead-of-european-council-in -meise/. 
underlying social relations (mode of governance) and do not behave much differently from anti-reformist veto players. ${ }^{9}$ Change agents in countries with a weak rule of law often lack the appropriate incentives, norms and skills to conduct reforms in a non-politicised, inclusive and long-term oriented way. There is evidence that many of the Eu's reformist "change agents" from postSoviet states and the Western Balkans, instead of respecting the rule of law, have (mis)used the law and the judicial/prosecutorial structures as a weapon against their political and economic competitors, who, once in power, behave in a similar way (Mendelski 2011, 2015; Börzel and Pamuk 2012; Natorski 2013; Popova 2012; Di Puppo 2010). Second, the empowerment and creation of few selected "independent" oversight and accountability institutions (e.g. anticorruption agencies, constitutional courts, and judicial councils) reflects a problematic focus on few selected leaders of key institutions that open up new channels of politicization and lack of democratic accountability. The judicialization of politics also reflects the capture of these institutions by domestic elites (Tudoroiu 2015) or transnational hegemonic actors (Hirschl 2009).

Let me provide some telling examples from $\mathrm{SEE}$, where the EU-supported and empowered political reformist change agents have misused the law and the newly created or empowered judicial structures. Rather than serving as a constraint, the law was employed instrumentally to empower reformist change agents. Important decisions were therefore based on fast track legislating, emergency ordinances, or presidential decrees without democratic oversight. Such decisions included the selection of the heads of the anti-corruption agency and the prosecution in Romania (Mendelski 2012), the creation of a specialized criminal court in Bulgaria (Kuzmova 2014), the restructuration of the court system in Albania (Peshkopia 2014: 123) and the bypassing of the Constitutional Court's decisions in Bulgaria to fulfill EU demands for judicial reform (Bozhilova 2007). The instrumentalization of law in turn produced considerable legal instability for magistrates (e.g. frequent changes in anticorruption legislation and in legislation on the organization of the judiciary). Furthermore, the misuse of law to promote pro-reformist change agents and loyal protégés has undermined the generality of rules. ${ }^{10}$

The cases of Kosovo and Bosnia even show that imported foreign judges and prosecutors tend to assimilate with existing social relations and are not immune to existing practices (e.g. corruption, politicization, misuse of law, etc.). See OSCE 2012; Radin 2014; Capussela 2015. Interviews with several judges from SEE. 
Similarly, reformist change agents have politicized and instrumentalized newly created or empowered prosecutorial and secret service structures. Evidence for such abuse comes from the wiretapping scandal in Macedonia, where the national security services (under the Gruevski government) operated "outside its legal mandate on behalf of the government, to control top officials in the public administration, prosecutors, judges and political opponents" (Priebe 2015). Abusive wiretapping, politicization and other transgressions of the law by secret service and anti-corruption institutions were reported also in Romania and Bulgaria. ${ }^{11}$ There is also probably more to come, given the recent revelations on the involvement of undercover secret service agents in the Romanian judiciary and the prosecution. ${ }^{12}$ Furthermore, there is evidence that most of the newly created integrity and anti-corruption structures (DNA, ANI) became non-transparent, unaccountable and politicized (Transparency International Romania 2012; Di Puppo 2010). The same is true for judicial councils (the best practice EU-model of court administration), which evolved into politicized, unaccountable and non-transparent bodies (see Bobek and Kosar 2014; Seibert-Fohr 2012; Coman 2014; KIPRED 2011; OSCE 2009, 2012; Sigma Montenegro 2012: 5). Even the newly created specialized criminal courts did not function as they were supposed to, and they were also criticized for undermining fundamental rights (Ivanova 2013; Kuzmova 2014). Last but not least, constitutional courts became in many SEE countries (and beyond) the embodiment of juristocracy (Hirschl 2009) and politicization (Popova 2012; Beširević 2014; Hipper 2015; Morlino/Sadurski 2010; Seibert-Fohr 2012; Coman 2014).

The EU (despite its rhetoric of neutrality and non-interference) has in reality constantly supported its own liberal change agents, and by doing so has disempowered some of the "guardians of the rule of law" (e.g. the Judicial Council and the Constitutional Court), especially when they were under the control of reform opponents. In Romania, the EU Commission criticized the Superior Council of Magistracy (CSM) when it was dominated by old-guard

11 http://www.novinite.com/view_news.php?id=149848; http://www.novinite.com/view _news.php?id=149818; https://gazetadespania.es/ccr-spune-ca-interceptarile-facute-de -sri-pentru-dna-sunt-neconstitutionale/; http://www.bzi.ro/sua-critica-interceptarile -abuzive-din-romania-114776. -by-secret-agents/; http://goo.gl/YQPJri; http://www.mediafax.ro/politic/basescu -prea-multi-procurori-au-trecut-judecatori-si-sunt-ofiteri-acoperiti-printre-magistrati -14109992 . 
members connected to the Social Democratic Party (PSD), claiming it was unaccountable and had conflicts of interests (European Commission 2008b: 7), while it remained tacit when comparable problems occurred some years later. For instance, the problematic selection process of the CSM president on January 52013 was accompanied by several irregularities, such as arranged voting, ${ }^{13}$ the appearance of President Basescu during voting day (which was interpreted by judges as pressure $)^{14}$ and allegations of politicization. ${ }^{15}$ As a result of the contested election, for the first time in history a hierarchically subordinate prosecutor (and alleged Basescu ally), Oana Schmidt Haineala, was elected as head of the CSM. Haineala's selection has resulted in contestations and open disapproval by judges, revocation of those judges who voted for her (Danilet, Ghica) and an opening of investigations by the DNA and ANI (National Integrity Agency) of those judges (Dumbrava, Neacsu) who criticized her selection. ${ }^{16}$ It should be noted that this division between the four judges reflected not only a personal conflict between CSM members (and three former friends from the same reformist camp), but also a broader division of interests within the judiciary, which has become polarized in the wake of EU-demanded reforms. The EU, by empowering and supporting contested change agents and their controversial reform tools, indirectly contributed to the increased level of polarization and conflict in Romania's judiciary and the political system (see Mendelski 2014).

Similarly, in July 2008 the European Commission criticized the verdicts of the PSD-dominated Constitutional Court for blocking anti-corruption reform,

13 http://www.luju.ro/dezvaluiri/anchete/denunt-voturile-sunt-aranjate-in-csm-oana -haineala-si-alina-ghica-deconspirate-cum-solicitau-membrilor-csm-sa-voteze-dupa -cum-pofteau-fostul-sofer-al-csm-angel-gabriel-rosca-dezvaluie-ce-mesaje-sms-a-gasit -intr-un-telefon-primit-pe-inventar-de-la-institut.

14 http://www.luju.ro/institutii/csm/lovitura-de-sistem-s-a-produs-un-procuror-a-ajuns -seful-csm-oana-schmith-haineala-a-fost-aleasa-contra-naturii-presedinte-al-consiliului -judecatoarea-alina-ghica-si-a-depus-candidatura-pentru-vicepresedintia-csm-exact -cum-a-prezis-lumeajustitiei-ro-la-ple?print=1.

15 http://www.evz.ro/scandal-intre-sefii-magistratilor-judecatori-contra-procurori -horatius-dumbrava-csm-s-1.html. See also http://www.luju.ro/institutii/csm/exclusiv -magistratii-s-au-dezlantuit-pe-forum-impotriva-sefei-iccj-livia-stanciu-considerand-ca -au-fost-tradati-sefa-csm-oana-haineala-e-acuzata-ca-a-numarat-voturile-ca-roberta -anastase-in-parlament-ex-presedintele-csm-horatius-dumbrava-dezvaluie-nu-am -r?print=1.

$16 \mathrm{http://www.luju.ro/institutii/csm/represaliile-statului-de-drept-in-numele-lui-basescu}$ -fostul-judecator-adrian-toni-neacsu-a-intrat-in-malaxorul-dna-la-cateva-luni-dupa-ce -intr-un-mail-trimis-alinei-ghica-a-devoalat-presupuse-legaturi-dintre-csm-si-traian -basescu-la-referendumul-de-demite. 
arguing that "a series of Constitutional Court decisions and legislative modifications made over the last year could seriously weaken the fight against corruption" (European Commission 2008: 12). This unprecedented and "doubtful critique" of the Constitutional Court (Stanciulescu 2010: 86) once again exhibited the "partisan" behavior of the EU (in favor of liberal and reformist change agents), and it weakened the legitimacy of a crucial oversight institution when it corrected constitutional and processual deficits of the fight against corruption. ${ }^{17}$ In contrast, reformist integrity and anti-corruption fighters (e.g. Monica Macovei, Daniel Morar, Laura Codruta Kövesi, Horia Georgescu), NGO representatives (Laura Stefan) and even reformist judges (Livia Stanciu, Camelia Bogdan, Cristi Danilet) were decorated with awards (e.g. European of the Year Award, Women of Courage, People for People, Courage in the pursuit of justice $)^{18}$ and were invited to Brussels ${ }^{19}$ and Washington (or the us embassy) ${ }^{20}$

17 The politicized, non-objective and instrumentalized fight against corruption has been confirmed by former secret service head in Romania, Darren White, and by President Basescu. Furthermore, there were problems with abuse of wire-tapping, and a lack of respect for the immunity of judges. See http://www.flux24.ro/acuzatii-explozive-ale-fostului-sef -us-secret-service-dna-face-dosare-politice-kovesi-nu-e-corecta-sri-si-sie-sunt-folosite -politic/; http://www.romanialibera.ro/actualitate/international/wikileaks---directorul -fbi-catre-kovesi--ascultati-telefoane-si-folositi-interceptarile-in-instanta-221977; http:// www.romaniatv.net/traian-basescu-tacerea-mea-are-o-limita-din-2015-dna-ul-face-un -joc-care-nu-e-al-romaniei_282537.html.

18 http://www.pna.ro/faces/cv_kovesi.xhtml; http://romania.usembassy.gov/policy/charge/ pr-04102014.html; http://stirileprotv.ro/stiri/actualitate/laura-codruta-kovesi-desemnataeuropeanul-anului-2016-sefa-dna-este-al-doilea-roman-care-castiga-acest-premiu.html; http://www.mediafax.ro/social/laura-stefan-castigatoarea-premiului-femeia-curajoasa -2015-acordat-de-ambasada-sua-ma-motiveaza-schimbarea-romaniei-cea-mai-dificila -situatie-martea-neagra-14124815.

19 http://www.dcnews.ro/oana-haineala-si-livia-stanciu-discutii-la-bruxelles-despre -mcv_3409o6.html. http://www.cotidianul.ro/haineala-a-mers-la-bruxelles-sa-atace -noua-putere -de-la-bucuresti-204428/.

20 http://www.luju.ro/dezvaluiri/evenimente/au-dat-buluc-la-marele-licurici-capeteniile -binomului-dna-sri-s-au-ingramadit-sa-i-stranga-mana-ambasadorului-sua-hans-klemm -de-ziua-americii-au-stat-incolonati-asteptandu-si-randul-laura-kovesi-marius-iacob -calin-nistor-eduard-hellvig-si-florian-coldea-n; http://www.luju.ro/magistrati/instante/ mai-usor-cu-ambasadele-judecatorul-ion-popa-de-la-curtea-de-apel-bucuresti-denunta -practica-sefilor-din-justitie-de-a-se-frange-in-fata-marilor-licurici-nefirescul-unor-astfel -de-intalniri-reiese-si-din-perspectiva-faptului-ca-ambasadorii-sau-ceilalti-dip; http:// www.luju.ro/dezvaluiri/evenimente/iohannis-sluga-americanilor-recunoastere -uluitoare-a-presedintelui-romaniei-de-ziua-unirii-acuzat-din-multime-cu-reprosul -iohannis-ai-ajuns-sluga-americanilor-ma-seful-statului-a-confirmat-decat-a-rusilor-tot -e-mai-bine-asa-recunoasterea-explica-de-ce-pol?print=1. 
as a sign for their support. ${ }^{21}$ All this empowerment continued despite the very controversial, non-transparent and politicized fight against corruption, which included deals with prosecutors, fabricated/invented files, ${ }^{22}$ controversial investigation methods of the prosecution, ${ }^{23}$ violation of fundamental rights, selectivity of prosecution, non-transparent selection of judges ${ }^{24}$ influence/ dependence from abroad, ${ }^{25}$ and a focus on perverse, quantitative indicators (track record). To be fair, judicial and prosecutorial structures have also been abused under the less liberal PSD government. After all, the abuse, capture and politicization of state structures in Romania is a systemic pathology that is independent of the party in power.

In sum, this section provided evidence for the EU's partisan empowering of questionable and unaccountable reformist elites in countries with a weak rule of law. By so doing, the EU gave them a free hand in conducting reforms without the necessary checks and oversight, which created possibilities for abusing reforms, the law and newly created or newly empowered judicial structures.

Giving reform ownership to domestic change agents who have vested interests and who abuse the rule of law can be highly problematic for establishing the rule of law. It also implies that EU-driven reforms (and in particular the struggle between EU-backed reformers and disempowered reform opponents) may reinforce political conflict and polarization, which in turn reinforces politicization and other pathologies (legal instability, lack of generality and enforcement). The relevant question for the $\mathrm{EU}$ is whether reformers should be externally empowered at all costs, and especially at the cost of undermining the formal legality of law as well as the principle of universalism and impartiality.

\subsection{The Problem of Biased Evaluation of the Rule of Law}

The third fundamental problem of EU conditionality is reflected in biased evaluation of the rule of law, which is reflected in the lack of an objective,

21 http://pubdocs.worldbank.org/en/849571449245481997/ICHA-2014-Event-Program.pdf.

22 http://www.luju.ro/dezvaluiri/cazuri-celebre/inscenarea-demascata-la-iccj-inalta -curte-l-a-condamnat-pe-fostul-sef-al-diicot-alba-ioan-muresan-la-7-ani-inchisoare-cu -executare-dupa-ce-i-a-fabricat-dosar-comisarului-traian-berbeceanu-procurorul

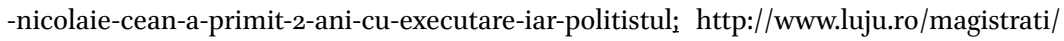
dna/daca-avea-dubii-dna-trebuia-sa-o-recuze-kovesi-vrea-sa-anuleze-hotararea-de -achitare-care-a-aruncat-in-aer-scaunul-sefei-iccj-pe-motiv-ca-judecatoarea -risantea-gagescu-nu-ar-fi-fost-impartiala-intrucat-nu-a-fost-promovata-la-inalta-curte -in-2013-pentru-ca.

23 http://www.tageswoche.ch/de/2016_9/international/712650.

24 http://m.romanialibera.ro/special/investigatii/revolta-celor-30o-din-justitie-181671.

25 http://www.euractiv.com/section/central-europe/opinion/why-the-west-wants-romania -to-be-less-corrupt/. 
consistent and sound assessment methodology (see Kochenov 2008; Schimmelfennig 2012; Carerra et al. 2013; Dimitrov et al. 2014; Toneva-Metodieva 2014; Mendelski 2016). In my opinion, the key problem is political. The European Commission (under the influence of many other actors) ${ }^{26}$ tends to better assess the rule of law during ruling periods of Eu-friendly, "liberal" governments than under EU-inimical "illiberal" governments, although in practice both types of domestic actors behave in a similar way with regard to (dis)respecting the rule of law. The main reason for politicized and biased assessment is probably to portray pro-EU change agents (e.g. pro-Western Ukrainian and Moldovan oligarchs) as democratic, rule-abiding, liberal elites, thus increasing their chances to win elections. And vice versa: the so-called "illiberal" reform opponents (e.g. Eastern-oriented oligarchs in Ukraine and Moldova) undergo a stricter assessment and more critical evaluations to discredit them in the eyes of voters. Similarly, domestic state structures (oversight institutions, prosecution and judicial structures) are repeatedly praised and evaluated positively when they are under the leadership of reformist "change agents", and are negatively assessed when they are under the control of reform-opposing "veto players".

Let me provide two examples to substantiate my argument. The first example of biased assessment of the rule of law comes from Romania. This was reflected in a partisan evaluation of a domestic "political conflict" (the constitutional crisis from 2012) between President Basescu and Prime Minister Ponta in the MCV progress report from July 2012 (European Commission 2012). ${ }^{27}$ The July MCV report assessed the "deliberate actions" 28 of the newly elected Ponta government and the PSD-dominated parliament (in the second week of July 2012) by claiming it had "serious doubts about the commitment to the respect of the rule of law" (European Commission 2012: 3). The Commission was "in particular extremely concerned by the indications of manipulations and pressure which affect institutions, members of the judiciary" (European Commission 2012: 3), and by the (mis)use of emergency ordinances (European

26 These actors of influence are, for instance, liberal domestic NGOs, reformist state representatives (judges, prosecutors) and external information providers (experts from liberal and transnational judicial networks). See page $24 \mathrm{ff}$.

27 This personal conflict reflects a broader ideological conflict in Romania between reformist change agents and reform-resisting opponents.

28 "These decisions appeared to deliberately remove effective Constitutional controls of political decisions. They included deliberate actions to limit the powers of the Constitutional Court, the replacement of several senior officials and changes to referendum rules. Some of these decisions were contrary to constitutional requirements. These events were accompanied by pressure against individual magistrates" (European commission 2012b: 4). 
Commission 2012: 20) by the Ponta government, which attempted to weaken the Constitutional Court and to dismiss the President as well as the Ombudsman and speakers of both houses of Parliament. ${ }^{29}$ It therefore gave the Romanian government a series of "specific urgent recommendations to address the current situation" (European Commission 2012: 20). ${ }^{30}$

In addition, the progress report was accompanied by an avalanche of heated debates and one-sided rhetoric by leading members of EU institutions. The "deliberate actions" of the Romanian government were denounced by liberal members of the European Parliament as a "coup d'etat" (former Minister of Justice Monica Macovei, Elmar Brok, Joseph Daul, etc.), ${ }^{31}$ and Commissioner Viviane Reding interpreted them as a "sort of parliamentary putsch"32 and "rule of law crisis". 33

29 http://www.venice.coe.int/webforms/documents/CDL-AD(2012)o26-e.aspx.

30 Among other were that "Repeal of Emergency Ordinance no 38/2012 and Emergency Ordinance no 41/2012 and ensure that Constitutional Court rulings on the quorum for a referendum and the scope of the Court's responsibilities are respected; Respect constitutional requirements in issuing emergency ordinances in the future; Implement all the decisions of the Constitutional Court; Ensure the immediate publication of all acts in the Official Journal, including decisions of the Constitutional Court; Require all political parties and government authorities to respect the independence of the judiciary; with a commitment to discipline any government or party member who undermines the credibility of judges or puts pressure on judicial institutions; Avoid any presidential pardons during the acting Presidency" (European Commission 2012: 20).

31 http://www.eppgroup.eu/fr/press-release/Roumanie\%3A-situation-politique-de-coupd'\% $3 \% 8$ gtat.

32 http://www.lemonde.fr/europe/article/2012/og/o1/viviane-reding-meme-en-crise-l-europe-n-est-pas-qu-un-marche_1754411_3214.html. Interestingly the online reference to Reding's controversial statement disappeared from Le Monde's website. The interview can be found here: http://www.scoop.it/t/l-europe-en-questions/?tag=Hongrie and here in Romanian http://revistapresei.hotnews.ro/stiri-subiectele_zilei-13138266-viviane -reding-nu-surprinsa-amanare-aderarii-romaniei-schengen.htm.

33 http://www.europeanvoice.com/article/imported/the-romanian-coup-d-etat/74831.aspx; http://europa.eu/rapid/press-release_SPEECH-13-677_de.htm. Interestingly, when the Eurosceptic President of the Czech Republic Vaclav Klaus was in a similar impeachment situation as President Basescu, no critical "coup d'etat" comments were raised by EU parliamentarians. The "coup d'etat" rhetoric by President Martin Schulz appeared more recently also in the Polish case, when the conservative PIs party attempted to check and disempower the politicized Constitutional Tribunal. See http://www.eazi.ro/prinlume/atentie-barroso-reding-gordon-gitenstein-lovitura-de-stat-in-cehia. http://www .telegraph.co.uk/news/worldnews/europe/poland/12051752/EU-parliament-head -refuses-to-apologise-over-coup-comment-after-Polish-PM-request.html. 
However, what the report did not mention was that: 1) the new government and parliament aimed to impeach the interventionist, prerogative-abusing and domestically delegitimized President Basescu (after a majority of Romanians expressed their disapproval in a referendum), who politicized state structures (secret service, the prosecution and the Constitutional Court) and undermined the separation of powers and judicial independence; ${ }^{34}$ 2) the Ombudsman Gheorghe Iancu was previously proposed by the Democratic Liberal Party (PDL), which President Basescu was closely linked to in the past (as the leader of the predecessor party); ${ }^{35} 3$ ) the Constitutional Court has issued abusive decisions in order to hamper the dismissal of President Basescu's impeachment (e.g. the introduction of a $50 \%$ quorum, delaying of the validation of the referendum);36 4 ) parts of the "independent" Constitutional Court's decision was drafted by Basescu's supporters from the CSM. ${ }^{37}$

Thus, while the socialist PSD government indeed attempted to take over power in a series of quick, politically motivated and deliberate actions, it is worth mentioning (for the sake of objective assessment) that politicization of state structures (including the misuse of emergency ordinances) were applied previously by Eu-friendly change agents (Minister of Justice Monica Macovei and President Traian Basescu), but were not criticized then by the EU. ${ }^{38}$ Interestingly, the instrumental (mis)use of laws and emergency ordinances was not mentioned in the progress reports from 2005 to 2007 , i.e. under Macovei's mandate, for instance when she transferred the appointment competences for prosecutors from the CSM to the Ministry of Justice through Law no. $247 / 2005 \cdot{ }^{39}$ This law was critically labeled "Macovei's law", 40 indicating the situational or personal interests behind it. This lack of generality of the law was later reflected in the conflicts between President Basescu and the PSD Minister

34 See interview by President Constantinescu for Die Tageszeitung Berlin, 5 September 2012: http://www.constantinescu.ro/interviuri/interviuri_53.htm. Confirmed by several anonymous Romanian judges. See also https://www.neweurope.eu/article/basescu -last-autocrat-europe.

http://www.ziare.com/pdl/stiri-pdl/pdl-il-propune-pe-iancu-gheorghe-ca-avocat-al -poporului-1102337.

36 http://www.constantinescu.ro/interviuri/interviuri_53.htm.

37 http://www.luju.ro/institutii/csm/toni-neacsu-detoneaza-bomba-in-csm-fostul -judecator-confirma-ca-erata-ccr-prin-care-basescu-a-scapat-de-demitere-in-urma -referendumului-din-2012-a-fost-elaborata-in-csm-sub-mandatul-sefelor-alina-ghica-si -oana-haineala-nu-este-un-zvon-este-o-realitate-era?print $=1$.

38 Interview with the president of the Romanian Association of Magistrates.

39 http://www.cdep.ro/pls/legis/legis_pck.htp_act?ida $=58107$.

40 http://www.criticatac.ro/22167/legea-macovei-cronica-unei-dezamgiri-anunate/. 
of Justice Monica Pivniceru over the nomination and appointment of the head of the anti-corruption agency (DNA) and the prosecutor general, reflecting a more systemic pathology. ${ }^{41}$

Last but not least, the political bias of the CVM report from July 2012 was so obvious that a number of international ${ }^{42}$ and domestic observers reacted with open letters and critique, among them Stelian Nastase and independent academics, ${ }^{43}$ as well as former judge of the constitutional court Viorel-Mihai Ciobanu, who criticized the Commission's nontransparent methodology and lack of objectivity. ${ }^{44}$ Among the critical voices was also former liberal President Emil Constantinescu, who criticized the European Commission for having issued a partisan, factually wrong and misleading assessment. ${ }^{45} \mathrm{He}$ assessed the EU's pressure as "unreal accusations that are contradicted by any correct and unbiased analysis of events and documents". 46

In sum, a politically neutral and systematic evaluation of the rule of law in Romania would have assessed the "deliberate actions" of the PSD government from July 2012 as a democratically legitimate and probably necessary counterreaction by the opposition towards previous politicization/instrumentalization of judicial structures by empowered change agents (President Basescu and various reformist actors in state structures). Instead, the EU reacted in a partisan way. It criticized veto players and at the same time supported (or abstained to criticize) change agents who applied questionable practices that abused the rule of law.

Another example of an inconsistent or partisan reaction by the EU (Commission and delegation) is related to the assessment of the rule of law in Moldova. This was most evident in the financial and rhetorical support of

$41 \mathrm{http}: / /$ stirileprotv.ro/stiri/mediafax/traian-basescu-respinge-numirea-lui-nitu-si-irimie -in-functia-de-procuror-general-si-de-sef-al-dna.html.

http://actmedia.eu/daily/heated-debates-among-mep-groups-over-the-political -situation-in-romania/42025.

43 http://www.stelian-tanase.ro/scrisoare-catre-uniunea-europeana-bruxelles/.

44 http://www.juridice.ro/221992/din-nou-despre-obstructionarea-justitiei-intrarea -in-vigoare-a-noului-cod-de-procedura-civila-atributiile-consiliului-superior-al -magistraturii-si-rolul-curtii-constitutionale.html.

45 The EU's too negative assessment in the controversial MCV July report was confirmed in my personal interview with an anonymous rapporteur who confessed that his initial report was much more positive than the final version.

46 http://www.nineoclock.ro/the-report\%E2\%80\%99s-dangerous-omissions. See letter by former president Constantinescu to the European Commission: http://www.nineoclock .ro/former-president-emil-constantinescu-writes-to-ec-president-jose-manuel-barroso/, http://www.dcnews.ro/212803_212803.html. 
reformist "change agents" (the Alliance for European Integration, AEI), whose leaders undermined the rule of law in practice. This was reflected in the politicization, division, ${ }^{47}$ and capture of judicial structures, as well as several criminal scandals that were related to the abuse of the rule of law (e.g. "Padurea domneasca", theft of one billion USD), misuse of courts in corruption scandals and "raider attacks" (fraudulent take-overs of companies and banks), and nonregistration (elimination) of a main political competitor (the Patria party, led by Renato Usati), allegedly through pressure on the Central Election Committee and arbitrary justice. ${ }^{48}$

The role of the EU (in particular the Commission and the EU delegation) contributed to this pathological development. Despite the instrumentalization of reforms and judicial structures, EU, US and IMF representatives continued to meet and support questionable reformist leaders (pro-Western oligarchs) from the AEI, for instance former Prime Minister Vlad Filat (who was recently convicted for corruption) and the controversial businessman and former first Deputy Speaker of the Parliament of Moldova, Vlad Plahotniuc. ${ }^{49}$ According to my interview with an EU delegation representative, the EU granted and prolonged "honey moon" periods. These were transitory periods after the regime change in 2009 during which leaders from the Alliance for European Integration (AIE) had free rein to bolster their power, which, however, turned some years later into too much unchecked power and abuse. The partisan support by the West of reformist AIE leaders was reflected, for instance, in the

47 The division of state structures among AEI leaders was documented in a secret appendix to the official alliance contract forming the political alliance.

48 http://www.osw.waw.pl/en/publikacje/osw-commentary/2015-04-22/appropriated -state-moldovas-uncertain-prospects-modernisation\#_ftn7. http://www.neweaster neurope.eu/interviews/1409-a-disappointing-victory. While the chief of the EC delegation in Chisinau expressed "deep concern" about the exclusion of the Patria party three days before the election, the EU's progress report from 2015 assessed this apparent abuse as a "deregistration", without any further comments (See European Commission 2015). http://unimedia.info/stiri/tapiola-o-schimbare-in-lista-electorala-cu-putin-timp -inainte-de-alegeri-provoaca-ingrijorare-85131.html. http://imrussia.org/en/analysis/ world/2121-moldova-eu-integration-at-all-costs.

http://www.trm.md/en/politic/premierul-vlad-filat-in-vizita-de-lucru-la-bruxelles/.: http://jurnal.md/en/politic/2016/5/13/the-exit-to-limelight-of-plahotniuc-and-his-visit -to-usa-yanukovich-was-either-not-lacking-photos-with-the-great-leaders-of-the -world/; http://www.intellinews.com/us-visit-of-moldovan-oligarch-plahotniuc-stirs -controversy-966o2/; http://unimedia.info/stiri/plahotniuc-isi-continua-periplul-in-sua --dupa-nuland--a-urmat-o-indrevedere-cu-un-director-de-la-fmi-114217.html. 
official meetings and support from EU and US representatives, ${ }^{50}$ as well as in very close personal relations with $\mathrm{EU}$ and Us diplomats, ${ }^{51}$ allowing them to obtain a carte blanche or "deal among friends" (see Belloni and Strazzari 2014). This in turn reduced accountability and opened up possibilities of undermining objective rule of law assessment and promotion, as well as the fight against corruption. By praising the reform "success story" of the AIE, the EU has supported a pro-EU reformist group that used questionable means of governing and reforming and that experienced shrinking legitimacy and public support. ${ }^{22}$ As a consequence, Moldova's "success story" has turned into the "EU's failed success story", or a "story of failure for the EU's Eastern Partnership", as admitted even by liberal voices such as Kalman Mizsei and Armand Gosu. ${ }^{53}$

Is there more systemic failure of $\mathrm{EU}$ conditionality? Nowadays, there is more and more evidence that so-called "successful laggards" (Noutcheva/Bechev 2008) have turned into unsuccessful ones. One key explanation for this failure points to the instrumentalization of rule of law reform and the judicial structures by reformist change agents (see Mendelski 2015; Börzel and Pamuk 2012). The wiretapping scandals in Macedonia and Bulgaria, the billion dollar theft in Moldova, the embezzling of foreign funds in Ukraine, Bulgaria and Romania, the authoritarian and politicized fight against corruption/crime in Georgia and the individual corruption scandals in Kosovo, Croatia, Moldova and elsewhere reflect the pathological consequences of previous politicization and concentration of power in the hands of empowered pro-Western elites. Rather than preventing these scandals, the EU's positive and partisan assessment and support of change agents, and its weakening of the opposition (as actors of

$50 \mathrm{http}: / /$ inprofunzime.md/stiri/politic/tot-mai-des-in-public-vlad-plahotniuc -a-participat-la-receptia.html; http://www.digi24.ro/Stiri/Digi24/Extern/Stiri/ PLAHOTNIUC+SUA+NULAND; http://shok.md/ultimele-stiri/prietenii-vlad-filat-si -donald-tusk-uite-i-cum-se-imbratiseazafoto.html; http://www.trm.md/ro/politic/ premierul-vlad-filat-in-vizita-de-lucru-la-bruxelles/; http://moldova24.info/2014/01/ despre-ce-au-discutat-filat-si-ambasadorul-sua/; https://point.md/ru/novosti/politika/filat-sa-intalnit-la-bruxelles-cu-preedintele-parlamentului-european; http://www .romania.mfa.md/news/482405/; http://www.rferl.org/content/Russia_In_Moldova _Soft_Power_Or_Soft_Force/219953o.html; http://www.publika.md/vlad-filat-s-a-intalnit -cu-ambasadorul-sua-in-moldova_692591.html; http://www.europalibera.org/a/24413712 .html.

$5^{1} \quad$ Interview with a former advisor to the government of Moldova.

$5^{2}$ Interview with Moldovan judges and civil society representatives, Chisinau 2011.

53 http://www.moldova.org/en/moldova-eus-failed-success-story/; http://www.hotnews .ro/stiri-opinii-20709654-analiza-republica-moldova-cosmarul-continua.htm. See also Kostanyan 2016. 
oversight), has actually opened the way for abuse of power, state structures and oversight institutions.

The EU's "deficit of rule of law assessment" is related to a wider set of interlinked issues. First of all, there is no sound and coherent methodology of rule of law assessment, which remains vague and flexible, opening the door for ad-hocness, leeway, partisanship and double standards. According to my interview with an EU representative, the European Commission follows a "problem-based approach" to rule of law reform. This means, basically, that the EU reacts to existing or newly arising problems of candidate countries. If a problem is not identified by the $\mathrm{EU}$, by contracted foreign or national experts, or when there is no ringing of 'alarm bells' by Western-financed NGOs or the international legal community, there is no need for the $\mathrm{EU}$ to become actively involved, e.g. to address the domestic problem in progress reports. ${ }^{44}$ What can be criticized is that the EU's reliance on a well-connected legal, liberal epistemic expert community and on Western-financed NGOs (which tend to shout less when pro-liberal governments violate the rule of law) can be problematic for an objective evaluation of the rule of law. The problem-oriented nature of the EU's approach has a significant shortage: it gives the EU considerable leeway with regard to admitting, stressing and evaluating a domestic problem, and with regard to the timing of its critical reaction. Thus, it can be argued that despite similar abuses of the rule of law, the alarm bells from NGOs, the international community and the European Commission only ring in the case of conservative, nationalist governments (see Mendelski 2016). ${ }^{55}$

The EU's "assessment deficit of the rule of law" (Mendelski 2016) springs also from a considerable information asymmetry during screening activities in candidate and problematic member countries. This problem is reflected in the issue that $\mathrm{EU}$ rule of law monitors and evaluators tend to meet mainly representatives from the legal, liberal and reformist camp (e.g. reformist change agents from liberal NGOS, the Constitutional Court, newly created judicial structures such as judicial councils and specialized agencies or courts that the EU promoted, EU diplomats, etc.). Similarly, the EU's information network consists mainly of adherents of the dominant liberal paradigm (e.g. constitutional democracy,

54 Interview with anonymous European Commission official.

55 Lack of alarm bells can be found in the case of Romania (when law and judicial structures were abused under the reformers President Basescu and Minster Macovei), in Hungary (when judicial independence deteriorated already under the liberal Gyurcsany government) and in Poland (when the liberal Civic Platform (PO) party under Tusk attempted to capture the Constitutional Court in July 2015). 
neo-liberalism, judicialization). ${ }^{56} \mathrm{~A}$ brief look at the Cvs of the judicial elite in SEE (especially Romania and Bulgaria) shows that leading magistrates are increasingly being trained and socialized in transnational epistemic communities (e.g. European Law Academy in Trier, at workshops and seminars organized by the EU, CoE, CEEELI, USAID and the World Bank) and are thus less inclined to criticize external conditionality (including its problematic reliance on international best standards, benchmarking). ${ }^{57}$ The same uncritical attitude towards external conditionality can be observed for legal reform practitioners who are keen to receive EU and Western funding and have high incentives for guarding critical information. This results in the donor pathology: "lessons not learned" (see Carothers 2003; Channell 2006)..$^{58}$ The key problem here is not representativeness in terms of institutional diversity but in terms of pluralism of information, which is not always guaranteed, and which restricts objective assessment of the rule of law.

In addition, I would argue that the bulk of the Eu's "independent" advisors, experts, rapporteurs and reviewers tend to be linked too closely to the EU (e.g. in terms of previous employment and collaboration) and to liberal networks, which may affect their independent assessment of the rule of law. A brief, selective glimpse at the Cvs of Eu Commission advisors might suffice here to back this argument. Most of the special advisors to the Commissioner of Justice (Reding, Timmermans) have either worked for the EU (Commission, Court of Justice) or have been linked to liberal transnational networks (e.g. Aspen Institute, European Council on Foreign Relations, World Bank, World Economic Forum $)^{59}$ or to diverse high-level judicial networks (e.g. the networks of the Presidents of Supreme Courts of the EU, ${ }^{60}$ the Association of

$5^{6} \quad$ Interview with an EU rapporteur.

57 This is my personal conclusion from my interviews and written communication with leading transnationally well-connected judges from CEE.

$5^{8}$ Interview with an international judge from the ECHR. According to Channell, "some of the best analyses are withheld by the donors due to political sensibilities. Critical assessments that include open, honest assessments of counterparts (including government, private sector, donor, and other counterparts) are withheld or sanitized to avoid controversy.... Information flow is thus cut off at the outset". With regard to lack of critical expert reports he argues that: “The writer's job is to provide information in such a way as to meet the client's expectations. One of those expectations is implementation success that will justify ongoing or new funding. If a report points out that some aspect of a project is not successful, this may affect the flow of funding" (Channell 2006: 15).

59 http://ec.europa.eu/civil_service/about/who/sa_en.htm.

6o http://www.networkpresidents.eu. 
the Councils of State and Supreme Administrative Jurisdictions of the $\mathrm{EU}^{61}$ or the European Network of Judicial Councils) ${ }^{62}$ (European Commission 2014: 9, see Parau 2015). This one-sided reliance on liberal experts and adherents of a liberal notion of democracy and the rule of law (i.e. with restriction of national sovereignty and the majoritarian demos) results in a restrictive legalconstitutionalist perspective that emphasizes only selective aspects of the rule of law (e.g. independence of Constitutional Courts and judicial councils), to the detriment of the accountability of these bodies. The consequence is a promotion of uniform models (e.g. liberal constitutionalism, court governance through judicial councils), to the detriment of an objective and systematic assessment of the rule of law as a socially, politically and historically embedded concept (see Carrerra et al. 2013).

For instance, the recent review example of EULEx (the EU's rule of law mission in Kosovo) has revealed the key problem of relying on well-connected EU experts. After the recent EULEX scandal, in which a British whistle-blower (who used to work for EULEX) accused her colleagues of corruption, Federica Mogherini (the EU's foreign policy chief) appointed an "independent expert", Prof. Paul Jacque, ${ }^{63}$ to "review" the corruption affair. Prof. Jacque's report from 30 March 2015 largely rejected the accusations that EULEX attempted to cover up the corruption of its officials. ${ }^{64}$ Investigations are not yet concluded, however question marks remain with regard to the appointment of the "independent" reviewer. It was reported that Prof. Jacque was previously an EU official: he was a director in the EU Council's legal services (between 1992 and 2008) and "worked for an institution which drafted the Eulex mandate" that he had to assess several years later. ${ }^{65}$

There are additional reasons for why information that would discredit liberal and reformist change agents may never reach progress reports or public attention. First, there is political and diplomatic influence on the content of the progress reports in the Secretariat of the European Commission, the Eu's delegations in the respective country and the Council (in the form of bilateral

\footnotetext{
61 http://www.aca-europe.eu/index.php/en.

62 http://www.encj.eu.

63 Mogherini justified this decision that he is "a distinguished Professor with over 40 years of experience" and that his appointment demonstrated the Eu's "determination to shed all light on these developments" http://eeas.europa.eu/statements-eeas/2014/141110_02 _en.htm.

64 The Jacque report can be found here: http://eeas.europa.eu/statements-eeas/docs/150331 _jacque-report_en.pdf.

65 https://euobserver.com/investigations/126468.
} 
pressure). ${ }^{66}$ The partisan and inconsistent evaluation of the rule of law by diplomatic EU representations in Moldova, Ukraine, and Georgia may especially be criticized here. It is related to geopolitical interests and was explained by the "democratization-stability dilemma" (Börzel and Hüllen 2014). There may also be tacit inaction by EU representatives, as reflected in the case of certain EULEX prosecutors, who refrained from investigating and prosecuting serious crimes committed by Kosovo's leading political elites (Capussella 2015). Second, the political and diplomatic influence inside the EU may exaggerate or understate identified problems concerning rule of law, even if initially de facto independent monitors and experts (e.g. from GRECO, OECD SIGMA, NGOs) provide a relatively objective picture. According to my interviews, Romania's SIGMA and GRECO reports on corruption and governance were much more negative than the final EU pre-accession reports, which omitted problematic issues that could have discredited change agents and delayed Romania's accession to the EU. ${ }^{67}$ Third, the perception of the rule of law in a country may be influenced by the European Parliament, and in particular a liberal network of parliamentarians and legal influential scholars. The most recent examples of potential influence and disinformation stem from the so-called "rule of law crises" in Romania, Poland and Hungary, when representatives from the liberal European People's Party became vocal and partisan defenders of previously empowered and politicized constitutional courts. Finally, there are also influential transnational judicial networks (Parau 2015; Piana and Dallara 2015) comprising legal scholars and constitutionalists that exert an intellectual, onesided influence that results in a focus on selected aspects of the rule of law (e.g. Judicial Independence, Constitutionalism).

Altogether, the different sources of less visible influence, both from within the $\mathrm{EU}$ and the international community, generate lots of one-sided "rhetoric action" - the "strategic use of norm-based arguments" (Schimmelfennig 2001: 63) - in pursuit of the Eu's ideological and political interest. Considering the biased evaluation of the liberal, reformist change agents, the Eu's rule of law promotion and assessment has become the object of political and ideological instrumentalization and manipulation (including unjustified normative rhetoric), a worrying tendency that legitimizes the abuse of the rule of law.

66 This is also the reason why the accession of Romania and Bulgaria was assessed as premature. Interview with a former European Commission representative.

67 Interviews with anonymous representatives from GRECO, SIGMA and an anonymous rapporteur. 
This article has discussed the "pathological turn" in Europeanization studies by identifying and providing evidence for several "pathologies of Europeanization" in the area of the rule of law, as reflected in increased politicization and the deterioration of the inner morality of law (legal instability, lack of generality and enforcement) in SEE. These pathologies have evolved in SEE (and beyond) into persisting structural deficiencies and have been reinforced by the EU's problematic approach to rule of law reform and assessment. In particular, I have criticized three fundamental problems of Europeanization: 1) valuing quantity over quality; 2) partisan empowerment of change agents; and 3) partisan assessment of the rule of law.

The exposure of fundamental problems and pathologies of Europeanization reveals the pathological turn in European Studies (Börzel and Pamuk 2012; Mendelski 2014, 2015). The awareness of the pathological effects of EU conditionality is particularly timely as several politicians as well as legal scholars argue that the EU has the legitimacy and potential tools to evaluate rule of law in membership countries (see Müller 2015; Closa and Kochenov 2016; Jakab and Kochenov 2016; Bogdandy and Sonnevend 2015). This argument seems premature given the EU's lingering rule of law evaluation deficit.

The EU's lack of objective assessment of the rule of law was exposed during the pre-accession (Kochenov 2008) and the post-accession periods in Romania and Bulgaria (Dimitrov et al. 2014; Toneva-Metodieva, 2014), in the application of EU conditionality towards European Neighbourhood Policy countries (Schimmelfennig 2012) and more recently during the so-called "rule of law crisis" in Romania from summer 2012, as demonstrated by this contribution. In Romania, the EU did not evaluate the rule of law in a systemic way (which would have included a holistic and temporal perspective), but applied instead an ad-hoc, inconsistent and partisan assessment of deliberate governmental actions vis-à-vis politicized horizontal accountability institutions (which had been previously empowered by the EU itself). Thus, it could be argued that the EU's "rule of law evaluation deficit" from the pre-accession period has recently been extended towards EU members (see Mendelski 2016).

Rather than being pure constitutional (or rule of law) crises, these recent inter-institutional conflicts in Romania (but also in Poland and Hungary) reflect political and ideological domestic conflicts in which EU institutions (Commission, Parliament) have interfered in a partisan way. To fully grasp these domestic power struggles, it is necessary to look into the past decade of (politicized) rule of law reforms and partisan empowerment by the $\mathrm{EU}$ and transnational reform coalitions (see Parau 2015). From such a chronological 
perspective, these recent constitutional/political crises represent in fact political backlashes and (democratically legitimized) counter-movements (Polanyi 1944) to a previous partisan, top-down empowerment of an elite group of reformist actors with compatible interests (including members from the judiciary and constitutional courts) (see Hirschl 2009). While such processes of empowerment and judicialization can be seen as a benign means to counterbalance previous "politicization" and negative effects of majoritarian democracy, the overzealous and one-sided promotion of judicial independence and constitutionalism has in recent years resulted in a profound imbalance to the detriment of democratic accountability and legitimacy. The so-called constitutional crises can thus be seen as the epitome of EU-driven partisan empowerment and politicized reforms, which have undermined accountability (over empowered judges and empowered liberal political elites), democracy (the will of the demos and the legitimized ruling majority) and aspects of the rule of law.

The theoretical implications are clear. The over-optimistic assumptions of a purely beneficial impact of Europeanization and of empowered "horizontal accountability institutions" (such as constitutional courts and anti-corruption agencies) cannot be sustained anymore. Under certain unfavorable conditions (e.g. conditions of weak institutional and democratic oversight), externallydriven judicial reforms by empowered and unaccountable reformers may lead to an abuse (politicization) of newly created or existing state structures and may therefore undermine the rule of law. This is not to say that "horizontal accountability institutions" (O'Donnell 1998; Schedler et al. 1999) do always have such pathological effects. Authors have previously identified also some positive effects of constitutional courts in more advanced post-communist countries and during the initial years following communism (Schwartz 20oo; Prochazka 2002; Ginsburg 2003; Morlino and Sadurski 2010). However, it is much more probable that creating effective and impartial oversight institutions is a nonlinear process (Trochev 2008) that can have unintended and even pathological consequences. The main reason for non-linear, context-dependent outcomes is that reform processes depend on the social, political and legal order in which reformers (including liberal change agents) are embedded. The Eu, by empowering and siding with empowered "liberal" change agents (from the judiciary and politics) during reforms in general and "inter-institutional conflicts" in particular, risks polarizing and amplifying domestic power struggles. Also, by evaluating the rule of law in a partisan way, the EU risks transforming this core fundamental value into a politicized and instrumental buzzword, rather than strengthening it as an impartial principle and constraint valid for all actors.

Having identified the EU's inability to objectively assess and effectively promote the rule of law in the past, I would argue that it should either 
abstain from evaluating the rule of law in the future or it should radically revise its approach. But how can further detrimental effects (pathologies) of Europeanization be avoided? The policy implications should be clear. The main message for practitioners and the EU is that how reforms are conducted matters. Successful judicial, anti-corruption and legal reforms should be evaluated in a non-partisan way, and there should be a greater focus on quality rather than on quantity and speed.

First, the EU needs to become more consistent and non-partisan in its assessment of governments. In particular, the EU should not be tacit when pro-EU, "liberal" elites from (former) candidate, accession or membership countries politicize judiciaries and horizontal accountability institutions. Neither should the EU grant "honeymoon periods" to pro-Western change agents after regimes changes (e.g. as in Moldova, Ukraine, Georgia, Serbia, Kosovo etc.), particularly when they break or misuse the law, disrespect human rights, engage in corruption or instrumentalize anti-corruption and judicial reforms. Rather than focusing on regime change and a few selected liberal change agents, the EU should reward reformers who apply an impartial, depoliticised and inclusive reform approach, it should foster (but not impose) domestic consensus, and finally it should regard the law as a necessary constraint rather than a tool. In addition, the EU's deficient rule of law evaluation methodology needs to become more systematic and transparent to avoid bias. For instance, the EU's progress reports could contain more detailed references and all relevant sources of information in a large appendix (e.g. containing original screening reports by experts, documented interviews, opinions of the respective government and opposition, etc.). More objectivity and validity through triangulation and transparency of the evaluation methodology could help to reduce the "EU's rule of law evaluation deficit" (see Mendelski 2016).

Second, Eu conditionality should shift its focus from quantitative outcomes towards qualitative processes. In particular, the EU should not link conditionality to specific reform outcomes or quantitative benchmarks (e.g. bringing war criminals before the court, increasing the number of high-level corruption cases, increasing the number of adopted laws or first-best practices). Rather, the EU should link conditionality to the reform process itself, which underlies these outcomes (including the use of process-related indicators). Thus, legal quality should not simply be assessed by the number of laws aligned with international standards, but instead by the inner quality of laws (i.e. clear, stable, coherent and enforced rules). Similarly, judicial quality should not simply be assessed in terms of the quantity of human and financial resources or efficiency indicators (as is currently done by CEPEJ or the EU Justice Scoreboard). 
Instead and much more attention should be paid to process-oriented quality, which considers impartial selection of accountable and professional magistrates or the "loyal cooperation" between institutional actors. Overall, this renewed focus on processes and quality should be embedded in a holistic and systemic approach, which focuses on all four key dimensions of the rule of law.

The lessons learned from this article are clear: first, having shown that the instrumentalization of reforms (in the name of Europe) may generate pathological outcomes, reform resistance and backslash is not necessarily something harmful, but can be seen as a mechanism to correct reform pathologies of Europeanization. Second, the EU needs to improve the currently flawed and inconsistent methodology of rule of law evaluation, which opens the doors to bias and double standards. An enhanced approach requires that the EU abandons the naive methodology of measuring the rule of law in a quantitative and additive way, employing instead a more objective, qualitative, systemic and multiplicative methodology, which pays attention to balancing rule of law dimensions (and components), reform processes, temporality/timing and the diverse domestic conditions (embeddedness) under which reforms are conducted.

\section{Acknowledgements}

I dedicate this article to all hardworking legal practitioners (who seek to promote the rule of law) and to Europeanization scholars (who seek to discover the EU's impact on domestic policies, politics and polities). Unfortunately, many of them have been too optimistic and have overestimated the "EU's transformative power" with regard to establishing the rule of law in South Eastern Europe. The reform and creation of the rule of law is much more complex and contested than assumed, considerably non-linear and context-dependent (i.e. historically, socially and politically embedded). These may be the reasons why liberal best practices and standard recipes often fail. I also acknowledge the useful comments from Artsiom Nazaranka, Ramona Coman, and two anonymous reviewers.

\section{References}

Belloni, R. and Strazzari, F. 2014. "Corruption in post-conflict Bosnia-Herzegovina and Kosovo: a deal among friends" Third World Quarterly 35(5): 855-871.

Beširević, V. 2014. "Governing without judges: The politics of the Constitutional Court in Serbia" International Journal of Constitutional Law 12(4): 954-979. 
Bobek, M. and Kosar, D. 2014. "Global Solutions, Local Damages: A Critical Study in Judicial Councils in Central and Eastern Europe" German Law Journal 15(2):1257-1292.

Bogdandy and Sonnevend, P. (eds.). 2015. Constitutional Crisis in the European Constitutional Area: Theory, Law and Politics in Hungary and Romania (Oxford: Hart).

Börzel, T. A. and Risse, T. 2003. "Conceptualizing the domestic impact of Europe" The politics of Europeanization, 57-80.

Börzel, T. A. 2015. "The noble west and the dirty rest? Western democracy promoters and illiberal regional powers" Democratization 22(3): 519-535.

Börzel, T. A. 2016. "Building Member States: How The E U Promotes Political Change In Its New Members, Accession Candidates, And Eastern Neighbors" Geopolitics, History \& International Relations 8(1): 76-112.

Börzel, T. A. and Pamuk, Y. 2012. "Pathologies of Europeanisation: fighting corruption in the Southern Caucasus" West European Politics 35(1): 79-97.

Börzel, T. A. and Van Hüllen, V. 2014. "One voice, one message, but conflicting goals: cohesiveness and consistency in the European Neighbourhood Policy" Journal of European Public Policy 21(7): 1033-1049.

Bozhilova, D. 2007. "Measuring Successes and Failures of Eu-Europeanization in the Eastern Enlargement: Judicial Reform in Bulgaria" European Journal of Law Reform 9(2): 285-319.

Caplan, R. 2005. "Who guards the guardians? International accountability in Bosnia" International Peacekeeping 12(3): 463-476.

Capussela, A. L. 2015. State-Building in Kosovo: Democracy, Corruption and the EU in the Balkans (London: IB Tauris).

Carothers, T. 2003. Promoting the rule of law abroad: the problem of knowledge.

Carrera, S., Guild, E., \& Hernanz, N. 2013. The Triangular Relationship between Fundamental Rights, Democracy and the Rule of Law in the $E U$ : Towards an EU Copenhagen Mechanism.

Channell, W. 2006. "Lessons Not Learned: Problems with Western Aid for Law Reform in Post-Communist Countries" Journal of Comparative Law 1(2): 321-337.

Closa, C. and Kochenov, D. 2016. (eds.). Reinforcing Rule of Law Oversight in the European Union (Cambridge: Cambridge University Press).

Coman, R. 2014. "Quo vadis judicial reforms? The quest for judicial independence in Central and Eastern Europe" Europe-Asia Studies 66(6): 892-924.

Dallara, C. 2014. Democracy and judicial reforms in South-East Europe. Between the EU and the legacies of the past (Cham: Springer).

Dimitrov, G., Haralampiev, K., Stoychev, S. and Toneva-Metodieva, L. 2014. The Cooperation and Verification Mechanism: Shared Political Irresponsibility between the European Commission and the Bulgarian Governments (Sofia: St. Kliment Ohridski University Press).

Dimitrova, G. 2002. "The limits of Europeanization: Hegemony and its misuse in the political field of Bulgaria" Southeast European and Black Sea Studies 2(2): 69-92. 
Di Puppo, L. 2010. "Anti-corruption interventions in Georgia" Global crime 11(2): 220-236.

Ekiert, G., Kubik, J. and Vachudová, M. A. 2007. "Democracy in the Post-Communist World: An Unending Quest?" East European Politics and Societies 21(1): 7-30.

Elbasani, A. (ed.). 2013. European integration and transformation in the western Balkans. Europeanization or business as usual? (New York: Routledge).

European Commission 2012a. Report from the Commission to the European Parliament and the Council on the Implementation by the Republic of Moldova of the Action Plan on Visa Liberalisation, Brussels, 22.6.2012, Сом(2012) 348 final, <http:// ec.europa.eu/home-affairs/doc_centre/external/docs/COM\%2oReport\%2o VLAP\%2oMoldova\%2oJune\%202012\%2oFINAL.PDF>.

European Commission 2012b. Technical Report Accompanying the Document Report From The Commission To The European Parliament And The Council On Progress in Romania under the Co-operation and Verification Mechanism $\{\mathrm{COM}(2012) 410$ final\}, Brussels, 18.7.2012 SWD(2012) 231 final

European Commission 2014. 'Communication: A New EU Framework to Strengthen the Rule of Law'. $\operatorname{com(2014)~} 158$ Final, 19.3.2014, <http://ec.europa.eu/justice/ effective-justice/files/com_2014_158_en.pdf >.

Falkner, G., Treib, O., \& Holzleithner, E. 2008. Compliance in the enlarged European Union: living rights or dead letters? (Ashgate Publishing, Ltd.).

Fuller, L. L. 1969. The morality of law (New Haven, London: Yale University Press).

Garoupa, N. \& Ginsburg, T. 2009. "The Comparative Law and Economics of Judicial Councils" Berkeley Journal of International Law 27(1): 53-83.

Ginsburg, T. 2003. Judicial Review in New Democracies: Constitutional Courts in Asian Cases (New York: Cambridge University Press).

Goetz, K. H. and Zubek, R. 2007. "Government, Parliament and Law-making in Poland" The Journal of Legislative Studies 13(4): 517-538.

Grabbe, H. 2006. The EU's transformative power. Europeanization through conditionality in Central and Eastern Europe (New York: Palgrave Macmillan).

Grzymala-Busse, A. M. 2002. Redeeming the communist past: The regeneration of communist parties in East Central Europe (Cambridge: Cambridge University Press).

Hayden, R. M. 2005. "Democracy' without a Demos? The Bosnian Constitutional Experiment and the Intentional Construction of Nonfunctioning States" East European Politics \& Societies 19(2): 226-259.

Hellman, J. S., Jones, G., \& Kaufmann, D. 2003. "Seize the state, seize the day: state capture and influence in transition economies" Journal of Comparative Economics 31(4): 751-773.

Hipper, A. M. 2015. Beyond the Rhetorics of Compliance: Judicial Reform in Romania (Springer). 
Hirschl, R. 2009. Towards juristocracy: the origins and consequences of the new constitutionalism (Harvard University Press).

Ivanova, I. 2013. "Rule of law in Bulgaria and the influence of EU Accession" in: Carrera, S., Guild, E., \& Hernanz, N. (eds.), The Triangular Relationship between Fundamental Rights, Democracy and the Rule of Law in the EU: Towards an EU Copenhagen Mechanism.

Jakab, A. and Kochenov, D. (eds.). 2016. The Enforcement of EU Law and Values (Oxford: Oxford University Press).

Karklins, R. 2005. The system made me do it: corruption in post-communist societies (ME Sharpe).

KIPRED. 2011. "The Inseparable Power: An analysis of the independence of the judiciary in Kosovo" <http://www.kipred.org/advCms/documents/84611_Inseparable _power_ENG_final.pdf >.

Kochenov, D. 2008. EU enlargement and the failure of conditionality. Pre-accession conditionality in the fields of democracy and the rule of law (Alphen aan den Rijn: Wolters Kluwer).

Kostanyan, H. 2016. "Why Moldova's European integration is failing” cEPS Commentary, 3 March 2016.

Kubicek, P. 2016. "Dancing with the devil: explaining the European Union's engagement with Ukraine under Viktor Yanukovych" Journal of Contemporary European Studies, 1-20. DOI: 10.1080/14782804.2016.1198689

Kuzmova, Y. 2014. "Bulgarian Specialized Criminal Court after One Year: A Misplaced Transplant, an Instrument of Justice, or a Tool of Executive Power" Boston University International Law Journal 32: 227-262.

Magen, A. and Morlino, L. 2009. International actors, democratization and the rule of law. Anchoring democracy? (New York: Routledge).

Maravall, J. M. 2003. "The rule of law as a political weapon" Democracy and the Rule of Law 5: 261-301.

Mendelski, M. 2011. "Rule of Law Reforms in the Shadow of Clientelism: The Limits of the EU's Transformative Power in Romania" Polish Sociological Review 2(174): 235-253.

Mendelski, M. 2012. “EU-Driven Judicial Reforms in Romania: A Success Story?” East European Politics 28(1): 23-42.

Mendelski, M. 2013. “They Have Failed Again! Donor-driven Promotion of the Rule of Law in Serbia" Südost-Europa: Zeitschrift für Politik und Gesellschaft 61(1): 79-113.

Mendelski, M. 2014. “The Limits of the European Union's Transformative Power: Pathologies of Europeanization and Rule of Law Reform in Central and Eastern Europe" (Doctoral thesis, University of Luxembourg 2014).

Mendelski, M. 2015. “The Eu's pathological power: The failure of external rule of law promotion in South Eastern Europe" Southeastern Europe 39(3): 318-346. 
Mendelski, M. 2016. "Das europäische Evaluierungsdefizit der Rechtsstaatlichkeit" Leviathan-Berlin Journal of Social Sciences 44(3): 366-398.

Morlino, L. and Sadurski, W. (eds.). 2010. Democratization and the European Union: comparing central and eastern European post-communist countries (Routledge).

Mungiu-Pippidi, A. 2014. "The Transformative Power of Europe Revisited" Journal of Democracy 25(1): 20-32.

Natorski, M. (2013). "Reforms in the judiciary of Ukraine: domestic practices and the EU's policy instruments" East European Politics 29(3): 358-375.

Müller, J. W. 2015. "Should the Eu Protect Democracy and the Rule of Law inside Member States?" European Law Journal 21(2): 141-160.

North, D. C., Wallis, J. J. and Weingast, B. R. 2009. Violence and social orders. A conceptual framework for interpreting recorded human history (Cambridge: Cambridge University Press).

Noutcheva, G. 2009. "Fake, partial and imposed compliance: the limits of the EU's normative power in the Western Balkans" Journal of European Public Policy 16(7): $1065^{-1084 .}$

Noutcheva, G. and Bechev, D. 2008. “The Successful Laggards: Bulgaria and Romania's Accession to the EU" East European Politics \& Societies 22(1): 114-144.

OSCE. 2009. "Legal analysis: independence of the judiciary" <http://www.osce.org/ skopje $/ 67584$ ?download=true $>$

OsCE. 2012. Independence of the Judiciary in Kosovo: Institutional and Functional Dimensions, <http://www.osce.org/kosovo/87138?download=true $>$.

Parau, C. E. 2015. "Explaining Governance of the Judiciary in Central and Eastern Europe: External Incentives, Transnational Elites and Parliamentary Inaction" Europe-Asia Studies 67(3): 409-442.

Peshkopia, R. 2014. Conditioning Democratization: Institutional Reforms and EU Membership Conditionality in Albania and Macedonia (London: Anthem Press).

Piana, D. \& Dallara, C. 2015. Networking the Rule of Law: How Change Agents Reshape Judicial Governance in the EU (Ashgate Publishing, Ltd.).

Polanyi, K. 1944. The great transformation: The political and economic origins of our time (Beacon Press).

Polishchuk, L. 2008. "Misuse of Institutions: Patterns and Causes" The Journal of Comparative Economic Studies 4: 57-80.

Popova, M. 2012. Politicized justice in emerging democracies: a study of courts in Russia and Ukraine (Cambridge: Cambridge University Press).

Pridham, G. 2005. Designing democracy. E.U. enlargement and regime change in postcommunist Europe (New York: Palgrave).

Priebe, R. 2015. "The former Yugoslav Republic of Macedonia: Recommendations of the Senior Experts' Group on systemic Rule of Law issues relating to the communications interception revealed in Spring 2015". 
Procházka, R. 2002. Mission accomplished: on founding constitutional adjudication in Central Europe (Kendall Hunt).

Radin, A. 2014. "Analysis of current events: towards the rule of law in Kosovo: EULEX should go" Nationalities Papers 42(2): 181-194.

Risteska, M. 2013. "The role of the EU in promoting good governance in Macedonia: towards efficiency and effectiveness or deliberative democracy?" Nationalities Papers $41(3): 431-446$.

Sadurski, W. 2004. "Accession's democracy dividend: The impact of the EU enlargement upon democracy in the new member states of Central and Eastern Europe" European Law Journal 10(4): 371-401.

Schimmelfennig, F. 2001. "The Community Trap: Liberal Norms, Rhetorical Action, and the Eastern Enlargement of the European Union" International Organization $55(1): 47-80$.

Schimmelfennig, F. 2012. "Europeanization beyond Europe" Living Reviews in European Governance 7(1): 1-31.

Schimmelfennig, F. and Sedelmeier, U. 2005. The Europeanization of Central and Eastern Europe (Ithaca: Cornell University Press).

Schwartz, H. 2000. The struggle for constitutional justice in post-communist Europe (University of Chicago Press).

Seibert-Fohr, A. 2012. Judicial independence in transition (Berlin: Springer).

Shapiro, M. M. 1988. Who guards the guardians?: judicial control of administration (Athens, GA: University of Georgia Press), 48-50.

Sigma Bosnia. 2012. "Bosnia and Herzegovina Assessment Report 2012" SIGMA Country Assessment Reports, 2012/o6, oECD, <http://dx.doi.org/10.1787/5jz2rqlcrnkd-en>.

Sigma Montenegro. 2012. "Montenegro Assessment Report 2012" SIGMA Country Assessment Reports, 2012/03, OECD, <http://dx.doi.org/10.1787/5jz2rqn827d2-en>.

Sigma Kosovo. 2011. "Sigma Assessment Report 2011" sigma Country Assessment Reports, 2011/05, OECD, <http://www.sigmaweb.org/publications/48970710.pdf>.

Simmons, B. A. 2009. Mobilizing for human rights: international law in domestic politics (Cambridge: Cambridge University Press).

Slapin, J. 2012. "How Membership in the European Union can Undermine the Rule of Law in Emerging Democracies" in APSA 2012 Annual Meeting Paper.

Slapin, J. B. 2015. "How European Union membership can undermine the rule of law in emerging democracies" West European Politics 38(3): 627-648.

Spendzharova, A. B. and Vachudova, M. A. 2012. "Catching up? Consolidating liberal democracy in Bulgaria and Romania after EU accession" West European Politics 35(1): 39-58.

Stewart, S. 2009. "The interplay of domestic contexts and external democracy promotion: lessons from Eastern Europe and the South Caucasus" Democratization 16(4): 804-824. 
Tamanaha, B. Z. 2004. On the rule of law. History, Politics, Theory (Cambridge: Cambridge University Press).

Teubner, G. 1998. "Legal irritants: good faith in British law or how unifying law ends up in new divergencies" The Modern Law Review 61(1): 11-32.

Toneva-Metodieva, L. 2014. "Beyond the Carrots and Sticks Paradigm: Rethinking the Cooperation and Verification Mechanism Experience of Bulgaria and Romania" Perspectives on European Politics and Society 15(4): 534-551.

Transparency International Romania 2012. National Integrity System Assessment Romania.

Trochev, A. 2008. Judging Russia: the role of the constitutional court in Russian politics 1990-2006 (Cambridge University Press).

Tudoroiu, T. 2015. "Democracy and state capture in Moldova" Democratization 22(4): $655^{-678 .}$

Vachudova, M. A. 2005. Europe undivided. Democracy, leverage, and integration after communism (Oxford: Oxford University Press). 